\title{
MANAJEMEN STRATEGI SUMBER DAYA MANUSIA PENDIDIKAN DI ERA 4.0
}

\author{
Sri Nurabdiah Pratiwi \\ Dosen Fakultas Keguruan dan Ilmu Pendidikan \\ Universitas Muhammadiyah Sumatera Utara \\ Email: Wiwikpratiwi20@Yahoo.Com
}

\begin{abstract}
Abstrak
Tren Pembelajaran Dan Penentuan Strategi Yang Sesuai Diharapkan Mampu Menghasilkan Peserta Didik Menghadapi Era 4.0 Bukan Hal Yang Mudah, Karena Berkaitan Dengan Penggunaan Tehnologi Dalam Kehidupan Manusia. Kemampuan Sumber Daya Manusia Menjadi Suatu Hal Mutlak Agar Mampu Bersaing Dan Survive Dalam Kehidupan. Pendidikan Sebagai Salah Satu Lembaga Penghasil Sdm Yang Berkualitas, Harus Menyusun Manajemen Strategis, Agar Bisa Menjawab Kebutuhan Sdm Di Era 4.0. Pendidikan Di Era 4.0 Melalui Beberapa Yang Memiliki Pola Berpikir Hots (Higher Order Thinking Skill). Sdm Pendidikan Yang Terdiri Dari Pengajar Dan Tata Usaha Memerlukan Pengetahuan, Dan Skill Tambahan Berkaitan Dengan Teknologi. Untuk Itu Perlu Disusun Formulasi Strategi Dan Implmentasi Strategi Yang Tepat, Sehingga Sdm Pendidikan Di Era 4.0 Benar-Benar Mumpuni Dan Mampu Menjawab Setiap Tantangan Yang Muncul. Pengembangan Dan Pemberdayaan Sdm Yang Sesuai Dan Tepat Akan Menumbuhkan Profesionalisme Dan Meningkatkan Kesejahteraan, Sehingga Lembaga Pendidikan Memiliki Kekuatan Untuk Bertahan, Tumbuh, Berkembang Dan Mampu Berkompetisi.
\end{abstract}

Kata Kunci: Manajemen Strategis, Sumber Daya Manusia, Era 4.0

\section{PENDAHULUAN}

Berada di Era 4.0 Mengharuskan Manusia Memiliki Kemampuan Dalam Menghadapi Kehidupan. Era Milenial Mengharuskan Manusia Dengan Berbagai Bentuk Kegiatan, Pekerjaan, Jasa, Usaha Dan Industi Menggunakan Teknologi Informatika Sebagai Alat Melancarkan Tugas Dan Kewajibannya. Berhadapan Dengan Era 4.0 Sumber Daya Manusia Harus Memiliki Strategi Agar Bisa Mengimbangi Dan Berhasil Di Era Tersebut

Pada Saat Ini Dan Kedepannya Sumber Daya Manusia (Sdm) Yang Diperlukan Pemerintah Pusat Maupun Daerah, Dunia Usaha, Dunia Industri, Pendidikan, Dan Organisasi Kemasyarakatan Adalah Sdm Yang Memiliki Skill, Kompetensi, Kapabilitas Dan Pengetahuan Yang Andal, Sehingga Kelak Nantinya Sdm Ini Menjadi Modal Dalam Membangun Bangsa. Pendekatan Manajemen Strategis Dalam Mengelola Sdm Sangat Dibutuhkan Terutama Dalam Menghadapi Era 4.0, Dimana Revolusi Industri 4.0 Merupakan Fenomena Yang Mengkolaborasikan Teknologi Cyber Dan Teknologi Otomatisasi. Konsep Penerapannya Berpusat Pada Konsep Otomatisasi Yang Dilakukan Oleh Teknologi Tanpa Memerlukan Tenaga Kerja Manusia Dalam Proses Pengaplikasiannya.

Memilih Sdm Yang Mampu Menjawab Tantangan Di Era 4.0 Atau Zaman Milenial Ini Hendaknya Menggunakan Manajemen Stratejik, Karena Manajemen Stratejik Merupakan Sutau Proses Penentuan Arah Dan Tujuan Organisasi Dalam Jangka Waktu Panjang Melalui Pemilihan Metode, Formulasi Strategi Dan Implementasi Yang Terencana Secara Sistematis. Dengan Kondisi Tersebut, Segala Bentuk Yang Berkaitan Dengan
Sdm Mampu Dilaksanakan Dengan Baik, Sehingga Dapat Mengurangi Kesalahan Dalam Memilih Sdm.

\section{METODE PENELITIAN \\ Manajemen Sumber Daya Manusia} Berdasarkan Beberapa Rumusan Sumber Daya Manusia (Sdm) Merupakan Orang Yang Mengerjakan Suatu Pekerjaan, Seperti Pegawai, Guru, Menteri, Direktur, Kepala Sekolah, Dan LainLain. Istilah Sdm Digunakan Untuk Lebih Mengenalkan Manusia Secara Umum Atau Universal Untuk Memperluas Kajian Yang Berkaitan Dengan Pekerjaan Masing-Masing. Sedangkan Rumusan Sumber Daya Manusia Yang Diidealkan Bangsa Indonesia Era Global. Tilaar (1998) Mengatakan Sumber Daya Manusia Abad 21 Adalah Manusia Yang Terus Menerus Belajar Dan Pentingnya Penghayatan Nilai-Nilai Indigenous. Menurut Mukhadis (1997) Bahwa "Sumber Daya Manusia Era Global Dituntut Memiliki Kemampuan (1) Berpikir Kritis, Peka, Mandiri, Dan Bertanggung Jawab; (2) Bekerja Secara Tim, Berkepribadian Yang Baik, Dan Terbuka Terhadap Perubahan, Serta Berbudaya Kerja Yang Tinggi; Dan (3) Berpikir Global Dalam Memecahkan Masalah Lokal, Dan Memiliki Daya Emulasi Yang Tinggi. Untuk Bisa Membantu Manusia Sesuai Dengan Rumusan Tersebut Dan Dengan Berbagai Karakter Dan Keinginan Dalam Pekerjaannya Diperlukan Pengaturan Atau Pengelolaan Yang Dapat Membuat Manusia Tersebut Bekerja Sesuai Dengan Keahliannya. Perlunya Pengaturan Pada Sumberdaya Manusia Atau Lebih Dikenal Dengan Manajemen Sumberdaya Manusia Karena Berkaitan Dengan Kebijakan, Praktik-Praktik Serta SistemSistem Yang Mempengaruhi Perilaku, Sikap Dan. 
Dessler (2015) Mengatakan Msdm Adalah Proses Untuk Memperoleh, Melatih, Menilai Dan Mengompensasi Pegawai, Dan Mengurus Relasi Kerja Mereka, Kesehatan Dan Keselamatan Mereka, Dan Hal-Hal Yang Berkaitan Dengan Keadilan. Selanjutnya Siagian (2014) Menambahkan Msdm Adalah Manusia Yang Merupakan Unsur Terpenting Dalam Setiap Dan Semua Organisasi, Keberhasilan Organisasi Mencapai Tujuan Berbagai Sasaran Dan Kemampuah Menghadapi Berbagai Tantangan, Baik Bersifat Eksternal Maupun Internal Sangat Ditentukan Oleh Kemampuan Mengelola Sumber Daya Manusia Dengan Setepat-Tepatnya, Masalah Pengembangan Diri, Keadilan, Kewajaran, Harapan Dan Kecocokan Pekerjaan Dengan Karakteristik Seseorang, Masalah Perilaku Organisasi Merupakan Bagian Pengelolaan Sumber Daya Manusia. Dari Kedua Pengertian Tersebut, Maka Manajemen Sumber Daya Manusia
Merupakan Proses Atau Kegiatan Untuk Mencapai Keberhasilan Tujuan Organisasi Melalui Berbagai Sasarannya Serta Kemampuan Meghadapi Berbagai Tantangan Internal Maupun Eksternal, Serta Menanamkan Kebijakan-Kebijakan, Sistem-Sistem Yang Mempengaruhi Perilaku, Sikap Dan Kinerja Manusia.

Dalam Kaitannya Dengan Pendidikan, Secara Sederhana Sumber Daya Manusia Terdiri Dari Tenaga Pendidik Dan Tenaga Kependidikan,. Tetapi Dalam Konteks Yang Lebih Luas Sdm Pendidikan Tidak Hanya Guru, Pustakawan, Laboran, Tata Usaha, Tetapi Juga Pengurus Yayasan Dan Juga Staf Pemerintah Yang Mengelola Pendidikan. Untuk Lebih Jelas, Maka Gambar Di Bawah Ini Akan Memperjelas Bagaimana Kaitan Pendidik Dan Tenaga Kependidikan Dalam Penyelenggaraan Kegiatan Pendidikan Dan Pembelajaran Di Sekolah

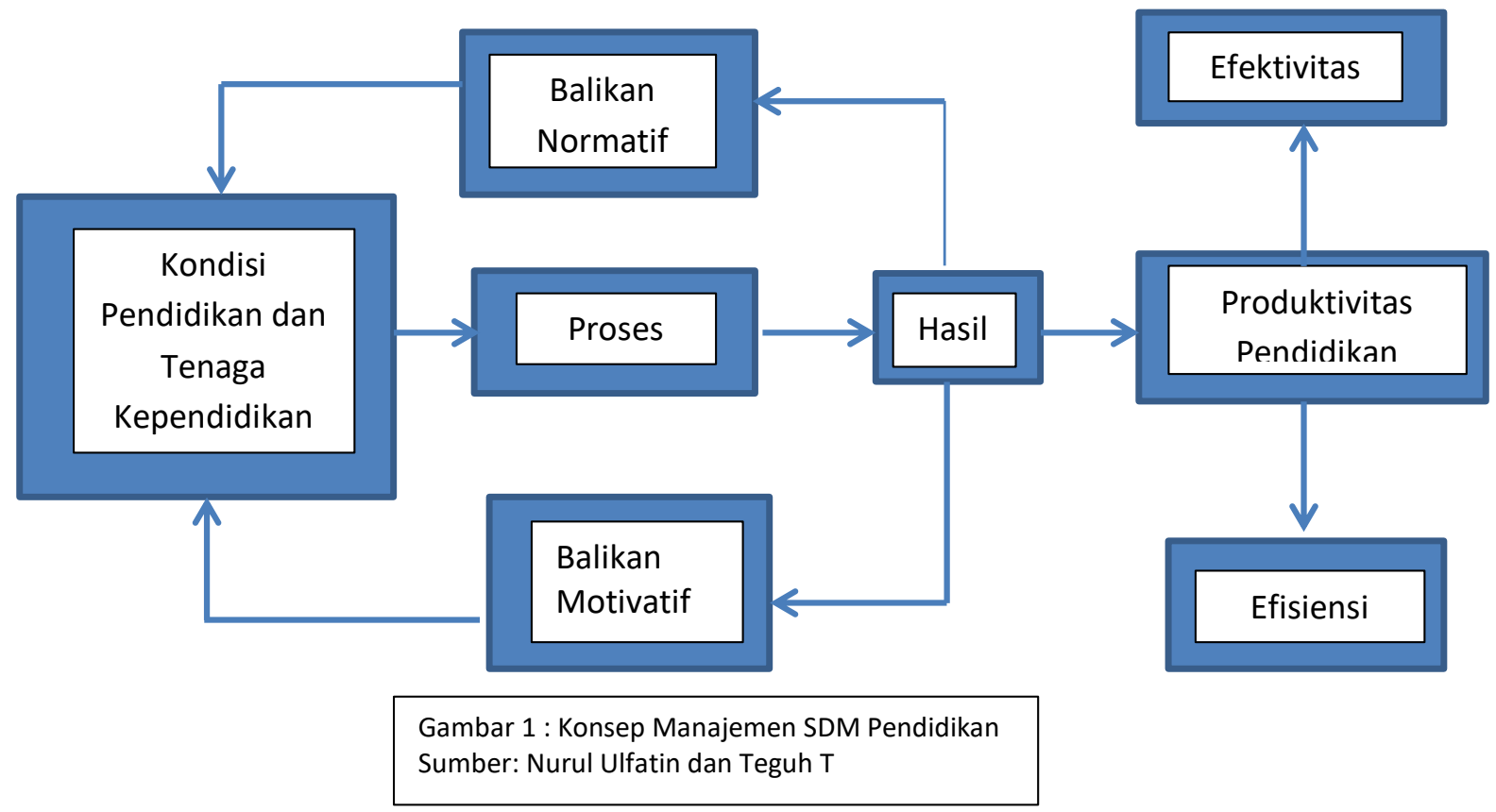

Secara Substansial Komponen Pendidik Dan Tenaga Kependidikan Merupakan Salah Satu Komponen Instrumental Input Yang Melakukan Proses Pendidikan Dan Pembelajaran Di Sekolah. Kedua Sdm Ini Memiliki Peran Strategis Sebagai Penentu Dan Pembuka Dalam Melaksanakan Kurikulum, Mengelola Sarana Dan Prasarana, Biaya Untuk Mengantarkan Peserta Didik Menjadi Luaran Yang Lebih Bermakna Dalam Kehidupan Di Masyarakat.

Untuk Mendapatkan Dan Memberdayaan Sdm Pendidikan, Diperlukan System Manajemen Yang Benar, Seperti Fungsi Manajerial Dan Fungsi Operasional, Fungsi Manajerial Dalam Sdm Meliputi Planning (Perencanaan), Organizing (Pengorganisasian), Directing ( Pengarahan),
Controlling (Pengawasan), Sedangkan Fungsi Operasional Lebih Rinci Dilakukan Seperti Pengadaan (Recruitment), Pengembangan (Development), Pembayaran (Compensation), Dan Pemutusan Hubungan Kerja (Separation). Jadi Dalam Penerapannya Sudah Direncanakan Bagaimana Melakukan Rekruitmen, Untuk Apa Dan Syarat Apa Yang Harus Dimiliki Sdm Yang Direkruitmen, Kemudian Pada Saat Kapan Dikembangkan, Bagaimana Dan Berapa Besar Compensasi Yang Diberikan, Dan Mengapa Terjadi Pemutusan Hubungan Kerja. Secara Lebih Jelas Dapat Kita Lihat Hubungan Fungsi Manajerial Dan Operasional Dalam Manajemen Sumber Daya ,Manusia Dalam Gambar Berikut 


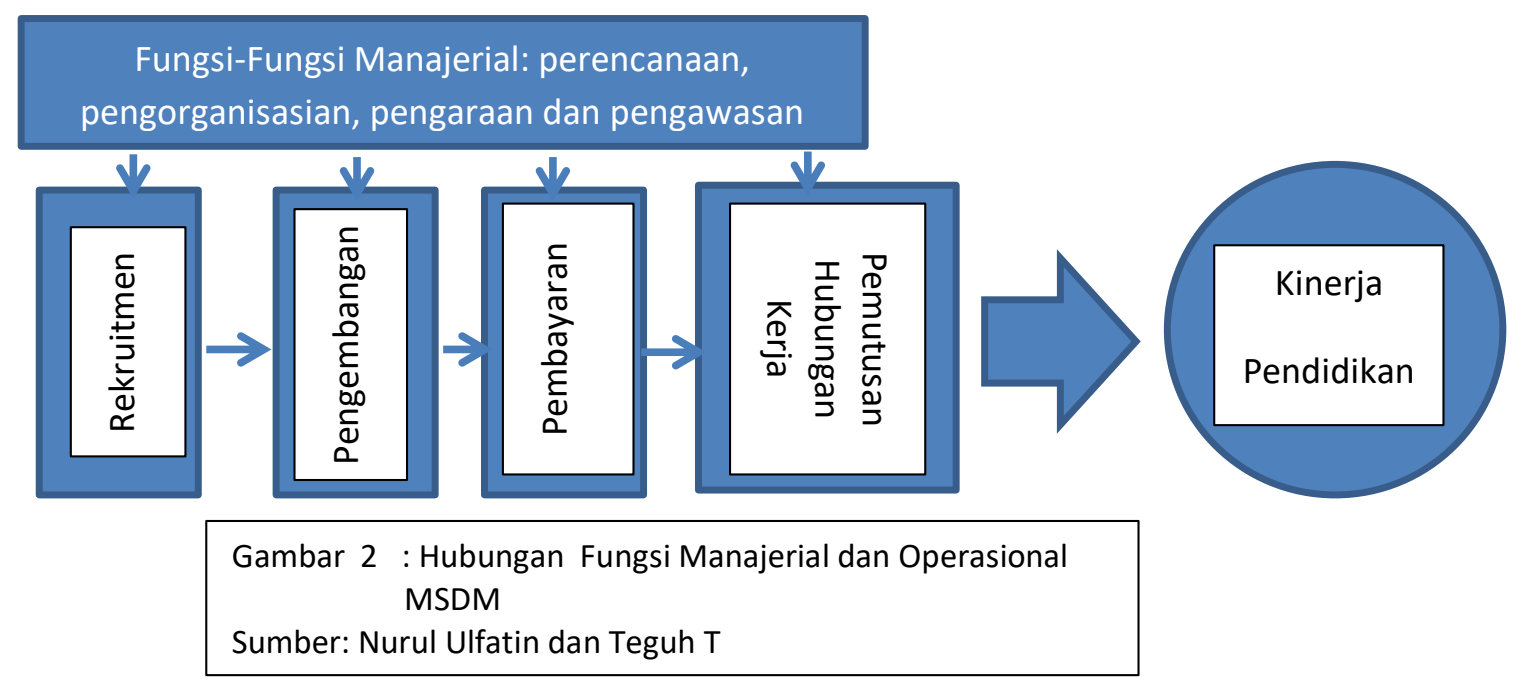

Manajemen Sumber Daya Manusia Terutama Sdm Pendidikan Di Era Saat Ini Ditekankan Pada Kemampuan Pengembangan Kompetensi Pendidik Dan Tenaga Kependidikan Melalui Program Pengembangan Dan Pemberdayaan Yang Dilakukan Secara Sistematik, Sehingga Sdm Dapat Bekerja Secara Professional. Pengembangaana Dan Pemberdayaan Sdm Merupakan Bagian Dari Manajemen Yang Memiliki Fungsi Memperbaiki Kompetensi, Adaptibilitas, Dan Komitmen Antara Pendidik Dengan Tenaga Pendidikan. Apabila Ini Dilakukan Secara Sitematis Dan Berkesinambungan Maka Organisasi Atau Lembaga Terutama Pendidikan Akan Memiliki Kekuatan Untuk Bertahan, Untuk Tumbuh, Untuk Lebih Produktif Dan Mampu Berkompetisi.

\section{HASIL dan PEMBAHASAN PENELITIAN Era 4.0}

Era 4.0 Sering Dikatakan Dengan Era Yang Seluruh Aktivitas Individu Dilakukan Dengan Menggunakan Alat Komunikasi Melalui Ponsel Yang Memiliki Kemampuan Tinggi Sehingga Mampu Melayani Kebutuhan Manusia, Hal Tersebut Menambah Nilai Efisiensi Terutama Dari Manajemen Waktu, Pada Suatu Lingkungan Kerja Di Mana Manajemen Waktu Dianggap Sebagai Sesuatu Yang Vital Dan Sangat Dibutuhkan. Selain Itu, Manajemen Waktu Yang Baik Secara Eksponensial Akan Berdampak Pada Kualitas Tenaga Kerja Dan Biaya Produksi. Pada Era 4.0 Manusia Sebagai Pelaksana Proses Kehidupan Menghadapi Tantangan Baru Terutama Dalam Dunia Kerja, Karena Ada Integrasi Antara Pemanfaatan Internet Dengan Hasil Yang Dicapai Melalui Pemanfaatan Kecanggihan Teknologi Dan Informasi. Ciri Khas Revolusi Industri 4.0 Meliputi Penggunaan Digitalisasi, Keoptimalan Dan Bentuk Produksi, Otomasi Dan Adapsi, Interaksi Antara Mesin-Manusia, Nilai Tambah Jasa Dan Usaha, Automatic Data Exchange And Communication, Dan Penggunaan Teknologi Internet. Keadaan Ini,
Harus Segera Dicari Jalan Keluarnya Melalui Transformasi Pasar Kerja Dengan Mempertimbangkan Perubahan Iklim Usaha Dan Dan Memperbaiki Budaya Industri, Serta Merubah Tata Cara Pergantian Jabatan Structural Yang Terjadi Pada Organisasi Dan Kebutuhan Keterampilan Yang Sesuai. Selanjutnya Untuk Mengantisipasi Lainnya Dapat Dilakukan Melalui Peningkatan Keterampilan Dan Kompetensi Yang Harus Dilakukan Secara Kontinyu Dan Konsisten Agar Kebutuhan Pasar Kerja Dapat Terpenuhi Sesuai Dengan Era Revolusi Industry 4.0.

Oleh Karena Itu Era 4.0 Sangat Erat Kaitannya Dengan Perubahan Besar Dalam Dunia Teknologi Bagi Semua Kehidupan Manusia, Termasuk Pendidikan. Mello (2015) Berpendapat Bahwa Sedikitnya Terdapat Tiga Dampak Bagi Organisasi Untuk Merespon Perubahan Teknologi Baru, Yaitu : (1) Perlunya Meningkatkan Sakills Dan Work Habits Pegawai, (2) Tersingkirnya Jabatan Tingkat Rendah Dan Level Manajerial, (3) Hirarki Berkurang, Lebih Berorientasi Pada Kerjasama Atau Kolaborasi Dan (4) Kehidupan Pekerja Pada Era Industry 4.0 Didominasi Oleh Self-Directed Striving For Personally Valued Career Outcomes. Jadi Dunia Pendidikan Dan Dunia Industri Secara Bersama-Sama Mampu Mengembangkan Srategi Transformasi Industri, Melalui Perkembangan Bagian Ketenaga Kerjaaan, Karena Salah Satu Keberhasilan Transformasi Industri Dilakuan Melalui Tenaga Kerja Yang Kompeten.

Menurut Siswoyo (2018) Dalam Menghadapi Revolusi Industry 4.0, Sedikitnya Ada Tiga Hal Yang Yang Perlu Diperhatikan Semua Pihak. Pertama Adalah Kualitas, Yaitu Upaya Menghasilkan Sdm Yang Berkualitas Agar Sesuai Dengan Kebutuhan Pasar Kerja Yang Berbasis Teknologi Digital. Kedua, Adalah Masalah Kuantitas, Yaitu Menghasilkan Jumlah Sdm Yang Berkualitas, Kompeten Dan Sesuai Kebutuhan Industri. Ketiga, Adalah Masalah Distribusi Sdm Berkualitas Yang Masih Belum Merata. 
Dunia Pendidikan Dalam Menghadapi Era 4.0 Sudah Harus Siap, Terutama Dari Sdm Nya. Inovasi Dalam Pembelajaran Sangat Dibutuhkan Sekali, Pembelajaran Dalam Kelas Bukan Lagi Hal Yang Wajib, Artinya Ruang Kelas Bukan Satu-Satunya Tempat Untuk Belajar. Melalui Inovasi Pembelajaran, Pendidik Sebagai Sdm Diharapkan Mampu Menyesuaikan Diri Dengan Perkembangan Teknologi Informasi Dan Komunikasi. Selain Penyesuain Terhadap Perkembangan Teknologi Tersebut, Yang Harus Diperhatikan Juga Pada Era 4.0 Adalah Perilaku Positip Yang Juga Perlu Dikembangkan, Sehingga Terjadi Keseimbangan Antara Kemajuan Teknologi Dengan Perilaku Individu Yang Mengedepankan Etika Yang Sesuai Dengan Kultur Bangsa Indonesia.

\section{Manajemen Strategis Sumber Daya Manusia} Era 4.0

Secara Umum Manajemen Strategis Merupakan Kumpulan Dan Tindakan Yang Menghasilkan Perumusan (Formulation) Dan Pelaksanaan (Implementation) Rencana-Rencana Yang Dirancang Untuk Mencapai Sasaran-Sasaran Organisasi. Yunus (2016) Menjekaskan Bahwa Manajemen Strategis Merupakan Proses Atau Rangkaian Keputusan-Keputusan Yang Bersifat Mendasar Dan Menyeluruh, Disertai Penetapan
Cara Melaksanakannya, Yang Dibuat Oleh Pimpinan Dan Diimplementasikan Oleh Seluruh Jajaran Dalam Suatu Organisasi Untuk Mencapai Tujuan. Sedangkan Susanto (2014) Mengatakan Manajemen Strategis Adalah Suatu Proses Untuk Menentukan Arah Dan Tjuan Organisasi Dalam Jangka Panjang Beserta Pemilihan Metode Untuk Mencapainya Melalui Pengembangan Formulasi Strategi Dan Implementasinya Yang Terencana Dan Sistematis. Berdasarkan Pengertian Tersebut, Maka Manajemen Strategis Perlu Ada Dalam Organisasi Karena Akan Membantu Terlaksananya Tujuan Organisasi, Melalui Metode, Formulasi Strategi Akan Diketahui Apa Yang Menjadi Kekuatan, Kelemahan, Kesempatan Dan Tantangan Organisasi. Sehingga Segala Kemungkinan Keberhasilan Ataupun Kegagalan Suatu Organisasi Dapat Ketahui Penyebabnya. Manajemen Strategik Memiliki Dua (2) Elemen, Yakni Formulasi Strategik Dan Implementasi Strategik. Formulasi Strategik Berkaitan Dengan Penentuan Visi, Misi, Arah, Sasaran Dan Tujuan. Sedangkan Implementasi Berkaitan Dengan Struktur, Sdm Dan Sistem Organisasi, Kesemuanya Ini Memerlukan Kepemimpinan Dan Budaya Yang Sesuai Dan Kokoh. Di Bawah Ini Merupakan Gambar Elemen Dalam Manajemen Strategic 


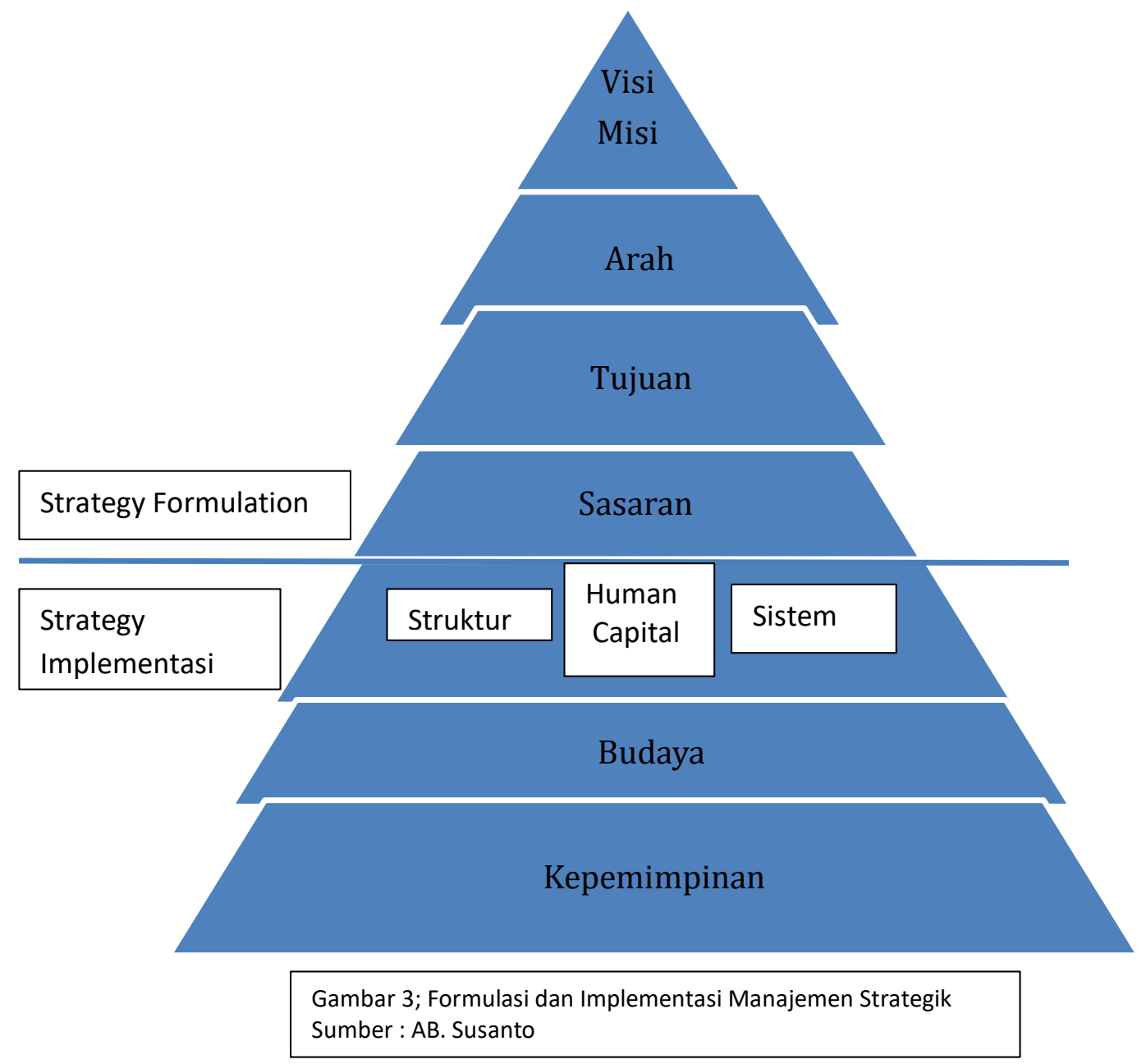

Susanto (2014) Jua Menjelaskan Bahwa Manajemen Strategi Penting Dalam Organisasi, Karena (1) Manajemen Strategik Membantu Menangani Ketidakpastian Melalui Pendekatan Sistematis (2) Manajemen Strategik Menyelaraskan Tujuan Antar Unit Dalam Organisasi, (3) Manajemen Strategic Membenahi Peran Serta Setiap Anggota Organisasi, (4) Manajemen Strategic Melatih Penerapan Budaya Dan Kepemimpinan, (5) Manajemen Strategic Menjadi Sarana Komunikasi Jangka Panjang Dan Acuan Bagi Dewan Direksi. Dari Ke 5 Pentingnya Manajemen Strategik Tersebut, Maka Dalam Dunia Pendidikan Hal Ini Juga Berlaku, Terlebih Di Era 4.0. Sdm Pendidikan Yang Berkutat Dengan Pembelajaran Dapat Menggunakan Kecanggihan Teknologi Komunikasi Sebagai Media Dalam Menjelaskan Pembelajaran. Manajemen Strategik Akan Membantu Semua Personil Sekolah Untuk Bisa Menggunakan Teknologi Canggih, Melalui Pendekatan Sistem Pelatihan, Work Shop Atau Kegiatan Lain Yang Bisa Membantu Proses Pendidikan Di Sekolah, Joenaidy (2019) Mengatakan Kecanggihan Teknologi Dapat BenarBenar Bermanfaat Maksimal Jika Seorang Pendidik Mau Mengembangkan Potensi, Meningkatkan Sdm Yang Ada Dan Mau Menggunakan Teknologi Tersebut Dalam Pembelajaran
Manajemen Strategi Sdm Pendidikan Di Era 4.0 Dapat Dimulai Dengan (1) Mengelola Kelas, Terutama Menghidupkan Rasa Nyama Anak Dalam Kelas, Dimana Kelas Yang Baik Akan Mampu Menjadi Rumah Kedua Bagi Siswa, Oleh Karena Itu Perlu Diperhatikan Strategi Dalam Mengelola Kelas Agar Mindset Peserta Didik Tidak Berkutat Pada Sistem Konvensional, Seperti Pengaturan Tempat Duduk, Menentukan Pasangan Duduk, Output Pembelajaran, Pembiasaan Dalam Kelas, Rotasi Tempat Duduk, Formasi Variasi Tempat Duduk. (2) Memilih Metode Dan Media Pembelajaran Yang Tepat. Metode Pembelajaran Merupakan Cara Yang Digunakan Guru Dalam Menyampaikan Pembelajaran, Metode Yang Tepat Akan Mengantar Siswa Mencapai Tingkat Tertinggi Dalam Pembelajaran. Pemanfaatan Teknologi Dapat Membantu Pemilihan Metoda Yang Sesuai. Kehadiran Dunia Industry Era 4.0 Dalam Pembelajaran Bukan Hanya Bagaimana Penggunaan Teknologi, Tetapi Dengan Teknologi Memudahkan Guru Dan Siswa Dalam Pembelajaran, Sehingga Akan Menghasilkan Metode Baru, Media, Dan Pengelolaan Kelas Yang Fleksibel, Tujuan Revolusi Industry 4.0, Dalam Dunia Pendidikan Salah Satunya Untuk Melatih Siswa Berpikir Hots (Higher Order Thinking Skill), Dengan Demikian Guru Menjadi Penentu 
Keberhasilan Siswa Dalam Berlatih Kemampuan Hots, Maka Penggunaan Media Dan Metode Pembelajaran Merupakan Langkah Awal Untuk Melatih Siswa Menggunakan Hots. Ada Beberapa Strategi Yang Dapat Dilakukan Untuk Melaksanakannya, Yakni: (A) Melalui Rumah Model Pembelajaran Seperti Discover Learning, Inquiry Learning, Project Based Learning Dan Problem Based Learning. (B) Memanfaatkan Lingkungan, (C) Penguasaan Materi, (D) Memperbaharui Pola Pikir. (3) Pemanfaatan Literasi 4.0, Yakni Berupa Literasi Data, Literasi Teknologi, Dan Literasi Manusia. Literasi Data Berkaitan Dengan Kemampuan Membaca, Menganalisis Dan Menggunakan Informasi (Big Data) Di Dunia Digital, Literasi Teknologi Berkaitan Dengan Memahami Cara Kerja Mesin Serta Aplikasi Teknologi Seperti Coding, Artificial Intelligence, Dan Engineering Principles, Dibutuhkan Waktu Untuk Mampu Menggunakannya, Sehingga Diperlukan Kreativitas Guru Agar Dapat Diraih Dengan Ber Agai Cara, Dan Akan Melahirkan Inovasi Dari Tehnologi Itu Sendiri. Literasi Manusia Berkaitan Dengan Kemampuan Manusia Menggunakan Tehnologi Tetapi Tidak Meninggalkan Jiwa Kemanusiaan. Ada 3 Hal Literasi Manusia Dalam Era 4.0 (A) Humanisme, Yakni Menumbuhkan Dan Mengembangkan Sikap Peduli Yang Tinggi Antar Sesama, Bergotong Royong, Bermasyarakat Yang Baik (B) Komunikasi, Merupakan Suatu Yang Sangat Utama Dalam Kehidupan Manusia, Kemampuan Komunikasi Yang Tinggi Akan Membantu Menyelesaikan Berbagai Masalah, (C) Desain, Bagian Penting Dalam Era 4,0, Kemampuan Desain Akan Terutama Dalam Pembelajaran Akan Menjadikan Kelas Lebih Dinamis Dengan Berbagai Bentuk Desain Pembelajaran Yang Berbeda-Beda Alam Setiap Pembelajaran. (4) Menggunakan Tren Pembelajaran 4.0. Pembelajaran Di Era 4,0 Tidak Tergantung Dalam Kelas, Tetapi Dapat Dilakukan Dimana Saja Dan Diwaktu Yang Tidak Terbatas. Joenaidy (2019) Menambahkan Bahwa Ada Beberapa Tren Pembelajaran 4.0, Diantaranya, Personal Learning Environments, Student Have A Choice In Learning, Project Based Learning, Modular Learning. Tren Pembelajaran Tersebut Dapat Digunakan Sesuai Dengan Kebutuhan, Sehingga Akan Muncul Nilai Kebermanfaatanya Bagi Guru Dan Siswa.

\section{KESIMPULAN}

Kemajuan Teknologi Era Revolusi Industry 4.0, Harus Dibarengi Dengan Kemampuan Sdm Dari Segi Skill, Kompetensi, Kapabilitas Dan Pengetahuan Yang Andal, Dan Juga Etika Moral Yang Tinggi. Pemberdayaan Dan Pengembangan Sdm Harus Mengikuti Pola Manajemen Yang Sesuai Dengan Kebutuhan. Di Era 4.0 Kehidupan Manusia Berada Dalam Lingkar Teknologi
Informasi, Sehingga Harus Disesuaikan Dengan Kondisi Bangsa Dan Masyarakat Indonesia. Lembaga Pendidikan Sebagai Salah Satu Pengguna Tehnologi Informasi Dan Komunikasi, Harus Bisa Memadu Dan Menyelaraskan Dengan Pembelajaran Di Sekolah. Adanya Tren Pembelajaran 4.0, Dapat Diaplikasikan Dalam Sekolah Yang Disesuaikan Dengan Jenjang Dan Tingkat Pendidikan. Peran Manajemen Sdm Menjadi Penting Untuk Menjawab Permasalahan Yang Timbul. Melalui Manajemen Strategik, Dapat Disusun Formulasi Strategic Dan Implementasi Strategic Untuk Membantu Peningkatan Kualitas Sdm Di Era 4.0

\section{DAFTAR PUSTAKA}

Dessler, Gari .2015. Manajemen Sumber Daya Manusia, , Jakarta, Salemba 4

Full_Paper_Sioswoyo_2018. The National Conference On Management And Business (Ncmab) 2018 Fakultas Ekonomi Dan Bisnis Universitas Muhammadiyah Surakarta

Jeffrey, Mello, A . 2015, Strategic Human Resource Management, 4th Edition, Cengage Learning Publisher

Joenaidy. Abdul Muis. 2019 Konsep Dan Strategi Pembelajaran Di Era Revolusi Industri 4.0., Jakarta: Laksana

Mangkuprawira. Tb. Syafri .2011. Manajemen Sumber Daya Manusia Strategik. Bogor: Ghalia Indonesia

Mukhadis, 1997. Fenomena Dialektika Sains Dan Teknologi: Implikasi Terhadap Perluasan Mandat Dan Orientasi Pembelajarannya. Makalah Pidato Ilmiah Dies Natalis Ke-43 Ikip Malang , 17 Oktober.

Sagala. Syaiful .2017. Human Capital. Membangun Modal Sumber Daya Manusia Unggul. Depok.: Kencana

Siagian, Sondang P . 2014. Manajemen Sumber Daya Manusia, Jakarta: Bumi Aksara

Susanto. Ab. 2014. Manajemen Strategik Komprehensif., Jakarta: Erlangga

Tilaar. H.A.R. 1998. Beberapa Agenda Reformasi Pendidikan Nasional Dalam Perspektif Abad 21. Magelang :Tera Indonesia.

(1997). Pengembangan Sumber Daya Manusia Dalm Era Globalisasi. Jakarta: Gramedia

Ulfatin, Nurul Dan Teguh Triwiyanto,2018. Manajemen Sumber Daya Manusia Bidang Pendidikan. Jakarta; Rajawali Press

Yunus. Eddy. 2016. Manajemen Strategis Yogyakarta: . Andi

Https://Www.Republika.Co.Id/Berita/Pendidikan/E duaction/18/05/27/P9d10c374-IniTantangan-Guru-Di-Era-Milenial Diakses 30 Oktobe 2019 